\title{
Calcium, diet and fracture risk: a prospective study of 1898 incident fractures among 34696 British women and men
}

\author{
Timothy J Key ${ }^{1, *}$, Paul N Appleby ${ }^{1}$, Elizabeth A Spencer ${ }^{1}$, Andrew W Roddam ${ }^{1}$, \\ Rachel E Neale ${ }^{2}$ and Naomi E Allen ${ }^{1}$ \\ 'Cancer Epidemiology Unit, University of Oxford, Richard Doll Building, Roosevelt Drive, Oxford OX3 7LF, UK: \\ ${ }^{2}$ Viertel Centre for Research in Cancer Control, Queensland Cancer Fund, PO Box 201, Spring Hill, Queensland \\ 4006, Australia
}

Submitted 29 August 2006: Accepted 18 January 2007: First published online 19 March 2007

\begin{abstract}
Objective: The risk factors for fractures are incompletely understood. An outstanding question concerns the optimal amount of dietary calcium needed to minimise the risk of fracture.

Design: We examined the associations of dietary calcium and other nutrients with selfreported fracture risk in a prospective cohort study. Nutrient intakes were estimated using a semi-quantitative food-frequency questionnaire administered at recruitment. Setting: The UK.

Participants: A total of 26749 women and 7947 men aged 20-89 years.

Results: Over an average of 5.2 years of follow-up, 1555 women and 343 men reported one or more fractures, $72 \%$ of these resulting from a fall. Among women, fracture risk was higher at lower calcium intakes, with a relative risk of 1.75 (95\% confidence interval (CI) 1.33-2.29) among women with a calcium intake of $<525 \mathrm{mg} \mathrm{day}^{-1}$ compared with women with a calcium intake of at least $1200 \mathrm{mg} \mathrm{day}^{-1}$ (test for linear trend, $P<0.001$ ). The association of dietary calcium with fracture risk was stronger among women aged under 50 years at recruitment than among women aged 50 and above. Dietary calcium intake was not associated with fracture risk in men. Fracture risk was not related to the dietary intake of any other nutrient examined.

Conclusion: In this population, women with a low dietary calcium intake had an increased risk of bone fracture, and this association was more marked among younger women than among older women.
\end{abstract}

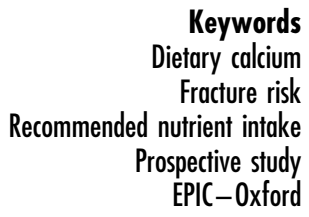

The importance of dietary factors in preventing bone fractures is controversial. Calcium has received the most attention, but even for this nutrient it has proved difficult to reach consensus on optimal intake. In the UK the estimated average requirement for calcium in adults is $525 \mathrm{mg} \mathrm{day}^{-1}$, and the associated reference nutrient intake $\left(700 \mathrm{mg} \mathrm{day}^{-1}\right.$ ) should be sufficient for $97.5 \%$ of people $\mathrm{o}^{1,2}$. In the USA, an estimated average requirement for calcium has not been set, but an adequate intake is set at $1000 \mathrm{mg} \mathrm{day}^{-1}$ for ages $19-50$ years and $1200 \mathrm{mg} \mathrm{day}^{-1}$ for ages 51 years and above ${ }^{3}$, and some experts have argued that even higher intakes of $1300-1600 \mathrm{mg} \mathrm{day}^{-1}$ would be ideal ${ }^{4}$. Other countries have produced varying recommendations, reflecting the limitations of data from balance studies and calcium accretion studies, and the inconsistent results of trials and previous observational studies of calcium intake and fracture risk ${ }^{5}$.

We report here results from the Oxford cohort of the European Prospective Investigation into Cancer and Nutrition (EPIC-Oxford), a prospective study of women and men in the UK. Recruitment into this cohort was designed to include people with varied dietary patterns and thus to cover wide variation in the intakes of nutrients including calcium ${ }^{6}$. Our principal aim was to examine the association of fracture risk with dietary calcium. We also examined the associations of fracture risk with dietary intake of seven other nutrients which have been suggested to be important for bone health: protein, vitamin $\mathrm{D}$, vitamin $\mathrm{C}$, retinol, carotene, potassium and magnesium.

\section{Methods \\ Participants and questionnaires}

The EPIC-Oxford cohort was recruited partly by postal methods targeted at vegetarians living throughout the UK, and partly through general practice surgeries in Oxfordshire, Buckinghamshire and Greater Manchester ${ }^{6}$. All participants completed a lifestyle questionnaire and foodfrequency questionnaire (FFQ), including questions relating to current height and weight, smoking habits, alcohol drinking, physical activity at work and during leisure time (including walking, cycling, other exercise or 
sport and amount of vigorous physical activity) and marital status $^{6}$. Women were also asked about their reproductive history and use of hormone replacement therapy. Participants' body mass index (BMI) was calculated as their self-reported weight in kilograms divided by the square of self-reported height in metres.

The FFQ required participants to estimate their average frequency of intake of each of 130 foods and drinks over the previous 12 months. Intake of tap or bottled water was not included on the questionnaire. Nutrient intakes were estimated by multiplying the nutrient content of a specific portion size of each food by the frequency of consumption, using food composition tables ${ }^{6-8}$. Nutrient intakes used in this analysis were energy, calcium, protein, vitamins $\mathrm{D}$ and $\mathrm{C}$, retinol, carotene, potassium and magnesium; other than energy, these nutrients were selected for analysis because they have previously been suggested to be important in maintaining bone health. Participants were also asked to report other aspects of their usual diet, including whether or not they had regularly taken any vitamins, minerals or other dietary supplements over the previous year.

The recruitment questionnaire was completed by 57450 participants aged 20 and above between 1993 and $2000^{6}$. About 5 years after completing the main questionnaire, surviving participants were sent a follow-up questionnaire. Participants were asked whether they had suffered any fractured bones over the previous 6 years, and to report the month and year of each fracture, the bone(s) affected and the cause, categorised as a fall, road traffic accident, other accident, fracture found only by X-ray or other causes. For this analysis, we defined an incident fracture as one occurring after the date of recruitment and involving bones other than the digits or ribs.

\section{Statistical metbods}

Follow-up questionnaires were available for 36956 participants. We excluded 240 participants who did not answer the question about fractures, 1360 who reported a fracture of the digits or ribs, or any type of fracture before recruitment, and 660 whose nutrient intake data were considered to be unreliable ( $\geq 20 \%$ of food frequencies missing, or daily energy intakes $<500 \mathrm{kcal}$ or $>3500 \mathrm{kcal}$ for women or $<800 \mathrm{kcal}$ or $>4000 \mathrm{kcal}$ for men). This left data for 34696 participants: 26749 women and 7947 men.

Dietary calcium intake was categorised as $<525$, 525699, 700-899, 900-1199 and $\geq 1200 \mathrm{mg} \mathrm{day}^{-1}$. The cut-off points for the two lowest intake categories corresponded to the UK estimated average requirement ( $525 \mathrm{mg} \mathrm{day}^{-1}$ ) and reference nutrient intake $\left(700 \mathrm{mg} \mathrm{day}^{-1}\right)$, respectively ${ }^{1}$, and the cut-off point for the highest intake category corresponded to the US adequate intake for ages 51 years and above $\left(1200 \mathrm{mg} \mathrm{day}^{-1}\right)^{3}$. Intakes of other nutrients were categorised into five groups of similar size each based on approximate quintiles of intake, except for retinol for which the highest intake category was $\geq 1000 \mu \mathrm{g} \mathrm{day}^{-1}$ in order to test the hypothesis that intakes above this level are associated with increased fracture risk.

Fracture incidence in relation to nutrient intakes was examined using Cox regression. Fracture-free survival time was calculated as the number of days from recruitment to the earliest incident fracture or the date of completion of the follow-up questionnaire for subjects who did not have an incident fracture. Analyses were stratified by method of recruitment (postal, general practitioners), and adjusted for the following factors: age at recruitment $(20-24,25-29,30-34,35-39,40-44,45-$ $49,50-54,55-59,60-64,65-69,70-74,75-79,80-89$ years), smoking (never, former, current cigarette smokers), log-transformed intakes of energy and each of the other nutrients under consideration, alcohol consumption $\left(<1,1-7,8-15, \geq 16 \mathrm{~g} \mathrm{day}^{-1}\right)$, BMI $\left(<20.0,20.0-22.4,22.5-24.9,25.0-27.4, \geq 27.5 \mathrm{~kg} \mathrm{~m}^{-2}\right)$, walking, $\left(<3,3-5,6-9, \geq 10 \mathrm{~h}_{\text {week }}{ }^{-1}\right)$, cycling $(0,0.5-$ $\left.1.5,2.0-4.5, \geq 5 \mathrm{~h} \mathrm{week}^{-1}\right)$, other exercise or sport (0, $0.5-$ $\left.1.5,2.0-4.5, \geq 5 \mathrm{~h}_{\text {week }}{ }^{-1}\right)$, amount of vigorous exercise

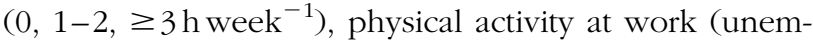
ployed or sedentary, standing, manual), marital status (married or living as married, unmarried) and, for women, number of children $(0,1-2, \geq 3)$ and use of hormone replacement therapy (never, past, current). Missing values existed for each of the non-dietary factors except for alcohol consumption and method of recruitment. To ensure that all relevant observations were included in each Cox regression analysis, 'unknown' categories were added for each of these factors. Data were analysed separately for women and men, and for women were also subdivided into 'younger' and 'older' women according to whether they were aged $<50$ years or $\geq 50$ years at recruitment.

Relative risks and 95\% confidence intervals (CIs) were calculated, with the lowest nutrient intake group as the reference category, except for calcium intake where the highest intake group was used as the reference category, and tests of trend were obtained by replacing the categorical nutrient intake variable by the logarithm of nutrient intake in the model. The significance of the difference in the association of calcium intake with fracture risk in women aged $<50$ years or $\geq 50$ years at recruitment was examined using a $\chi^{2}$ test for heterogeneity. Analyses were performed using STATA version 9.0?.

\section{Results}

The median age at recruitment was 46 years. The prevalence of smoking, the mean intake of alcohol and the mean BMI among participants were all low, and many subjects reported at least $3 \mathrm{~h}$ of vigorous exercise each week (Table 1). Mean calcium intakes in both women and men were above the UK reference nutrient intake of $700 \mathrm{mg} \mathrm{day}^{-1}, 18.1 \%$ of participants had a calcium intake below $700 \mathrm{mgday}^{-1}$ and $6.3 \%$ of participants had a 
Table 1 Baseline characteristics

\begin{tabular}{|c|c|c|}
\hline Characteristic & Women & Men \\
\hline Number & 26749 & 7947 \\
\hline Age at recruitment (years) & $45.8(13.1)$ & $49.5(13.5)$ \\
\hline Current smoker $(\%)^{*}$ & 8.9 & 11.5 \\
\hline Alcohol consumption $\left(\mathrm{g} \mathrm{day}^{-1}\right)$ & $7.7(9.6)$ & $15.1(17.8)$ \\
\hline Body mass index $\left(\mathrm{kg} \mathrm{m}^{-2}\right)^{*}$ & $23.6(3.9)$ & $24.2(3.3)$ \\
\hline$\geq 3 \mathrm{~h}$ vigorous exercise per week $(\%)^{*}$ & 27.6 & 34.3 \\
\hline Current HRT use $(\%)^{*}$ & 13.5 & - \\
\hline Energy intake (MJ day $\left.{ }^{-1}\right)$ & $7.89(2.09)$ & $9.02(2.41)$ \\
\hline Calcium intake $\left(\mathrm{mg} \mathrm{day}^{-1}\right)$ & $996(329)$ & $1046(363)$ \\
\hline$<525(\%)$ & 6.4 & 5.9 \\
\hline $525-699(\%)$ & 12.0 & 11.5 \\
\hline $700-899(\%)$ & 22.3 & 19.1 \\
\hline $900-1199(\%)$ & 34.9 & 32.9 \\
\hline$\geq 1200(\%)$ & 24.5 & 30.5 \\
\hline Protein $\left(\right.$ g day $\left.^{-1}\right)$ & $73.1(21.6)$ & $77.8(22.6)$ \\
\hline Vitamin D ( $\mu$ g day $\left.^{-1}\right)$ & $2.70(1.90)$ & $2.73(1.99)$ \\
\hline Vitamin C (mg day $\left.{ }^{-1}\right)$ & $143.1(68.3)$ & $125.4(60.6)$ \\
\hline Retinol $\left(\mu \mathrm{g} \mathrm{day}^{-1}\right)$ & $487.5(511.9)$ & $551.7(668.6)$ \\
\hline Carotene $\left(\mu \mathrm{g} \mathrm{day}^{-1}\right)$ & $3380(2021)$ & $3084(1860)$ \\
\hline Potassium (mg day ${ }^{-1}$ ) & $3811(984)$ & $3968(991)$ \\
\hline Magnesium (mg day $\left.{ }^{-1}\right)$ & $352.2(95.4)$ & $385.2(106.8)$ \\
\hline Regularly take dietary supplements $(\%)^{*}$ & 61.2 & 44.2 \\
\hline
\end{tabular}

HRT - hormone replacement therapy.

Values are mean (standard deviation), except where indicated.

*Unknown for some subjects (percentages are calculated among those with a known value of the factor).

calcium intake below $525 \mathrm{mgday}^{-1}$. Mean intakes of protein, vitamin $\mathrm{C}$, vitamin A (retinol equivalents), potassium and magnesium were all above the corresponding UK reference nutrient intakes. Fifty-seven per cent of participants reported regular use of dietary supplements.

A toal of 1555 (5.8\%) of the women and 343 (4.3\%) of the men reported having had one or more incident fractures in more than 182000 person-years of follow-up (Table 2). The most common fracture sites were wrist/arm and ankle, accounting for 43 and $15 \%$ of the incident fractures in women and 37 and $15 \%$ of the incident fractures in men, respectively. More than half of the fractures ( $75 \%$ in women and 56\% in men) were caused by a fall.

Table 3 shows for women and men the numbers of incident fractures and the multivariable adjusted incidence rate ratios relative to the reference category for each nutrient (except for energy which was regarded as a potential confounding variable). Based on the trend tests, only dietary calcium intake among women was associated with fracture risk. Among women, there was a significant inverse association between calcium intake and fracture risk ( $P<0.001$ for trend), with fracture risk being $75 \%$ (95\% CI 33-129\%) higher among women with a calcium intake of $<525 \mathrm{mg} \mathrm{day}^{-1}$ compared with women with a calcium intake of at least $1200 \mathrm{mg} \mathrm{day}^{-1}$. Calcium intake was not significantly associated with fracture risk in men, although the highest risk was observed in the lowest calcium intake category. The results were similar when the analyses were restricted to fractures resulting from a fall; relative risks for calcium intakes of $<525 \mathrm{mg} \mathrm{day}^{-1}$ compared with calcium intakes of at least $1200 \mathrm{mg} \mathrm{day}^{-1}$ were 1.83 (95\% CI 1.34-2.51) among women and 1.22 (95\% CI 0.55-2.73) among men.

The association between calcium intake and fracture risk in women was examined further among women aged $<50$ and $\geq 50$ years at recruitment (Table 4 ). In the younger women, there was a significant inverse association between calcium intake and fracture risk $(P<0.001$ for trend); there was also a decrease in fracture risk associated with increasing calcium intake among older women, although the test of trend was not statistically significant $(P=0.20)$. The difference in trends according to age was of borderline statistical significance $\left(\chi_{1}^{2}=3.77, P=0.05\right)$.

Fifty-seven per cent of subjects reported that they regularly took dietary supplements; the proportions taking supplements were $61 \%$ in the lowest dietary calcium intake category and 58\% in the highest dietary calcium intake category. The calcium content of dietary supplements was coded for a representative sample of 202 women who had reported that they were using a dietary supplement; 73\% were taking supplements which did not contain calcium, 19\% were taking supplements containing between 20 and $500 \mathrm{mg}$ of calcium, and $8 \%$ were taking supplements containing at least $700 \mathrm{mg}$ of calcium. The mean intake of calcium from supplements among these women was $95 \mathrm{mg} \mathrm{day}^{-1}$. We repeated the main analyses excluding subjects who reported regular use of dietary supplements. In this subanalysis, 595 out of 10726 (5.5\%) women and 203 out of 4495 (4.5\%) men reported having had one or more incident fractures. Results were similar to the main analysis, with only calcium intake in women, especially younger women, showing a clear association with fracture risk $(P=0.002$ 
Table 2 Site and cause of first incident fracture

\begin{tabular}{|c|c|c|c|c|c|c|}
\hline \multirow[b]{2}{*}{$\begin{array}{l}\text { Site of bone broken } \\
\text { in first incident fracture }\end{array}$} & \multicolumn{6}{|c|}{ Cause of first incident fracture } \\
\hline & Fall & $\begin{array}{l}\text { Road traffic } \\
\text { accident }\end{array}$ & Other accident & Found on X-ray & $\begin{array}{l}\text { Other, multiple } \\
\text { or unspecified }\end{array}$ & Total (\%) \\
\hline \multicolumn{7}{|l|}{ Women } \\
\hline Wrist/arm & 563 & 12 & 46 & 2 & 41 & $664(42.7)^{\star}$ \\
\hline Ankle & 203 & 3 & 10 & 2 & 16 & $234(15.0)$ \\
\hline Foot & 127 & 4 & 9 & 8 & 42 & $190(12.2)$ \\
\hline Leg & 94 & 13 & 14 & 0 & 13 & $134(8.6)$ \\
\hline Shoulder & 19 & 1 & 6 & 0 & 2 & $28(1.8)$ \\
\hline Hip & 29 & 1 & 6 & 1 & 5 & $42(2.7)$ \\
\hline Other or unspecified & 132 & 32 & 40 & 11 & 48 & $263(16.9)$ \\
\hline Total (\%) & $1167(75.0)$ & $66(4.2)$ & $131(8.4)$ & $24(1.5)$ & $167(10.7)$ & 1555 \\
\hline \multicolumn{7}{|l|}{ Men } \\
\hline Wrist/arm & 83 & 1 & 34 & 1 & 8 & $127(37.0)$ \\
\hline Ankle & 34 & 3 & 7 & 0 & 6 & $50(14.6)$ \\
\hline Foot & 16 & 2 & 1 & 0 & 7 & $26(7.6)$ \\
\hline Leg & 14 & 2 & 11 & 1 & 2 & $30(8.7)$ \\
\hline Shoulder & 11 & 3 & 4 & 0 & 1 & $19(5.5)$ \\
\hline Нip & 7 & 1 & 2 & 1 & 0 & $11(3.2)$ \\
\hline Other or unspecified & 27 & 9 & 29 & 2 & 13 & $80(23.3)$ \\
\hline Total (\%) & $192(56.0)$ & $21(6.1)$ & $88(25.7)$ & $5(1.5)$ & $37(10.8)$ & 343 \\
\hline
\end{tabular}

*Percentages may not sum to 100 due to rounding.

for trend for all women, $P<0.001$ for trend among women aged $<50$ years at recruitment; other results not shown).

\section{Discussion}

We observed a significant inverse association between estimated dietary calcium intake and fracture risk among women, but not among men. The association was stronger among women aged under 50 at recruitment than among older women.

Although fractures were self-reported, previous studies have shown that self-report is relatively accurate for several important fracture sites, including those of the hip, wrist and humerus ${ }^{10,11}$. The dietary questionnaire has been shown to provide valid estimates of calcium intake when compared with estimates from weighed food intakes: Spearman's rank correlation between the two estimates of calcium intake was $0.5^{12}$. We did not have complete data on calcium intake from dietary supplements, but there was little difference in supplement use between subjects with high and low dietary calcium intakes, and we estimated that $>80 \%$ of women did not take calcium supplements. This is consistent with other recent UK data from the National Diet and Nutrition Survey in which inclusion of supplements increased the mean daily intakes of calcium by only $32 \mathrm{mg}$ in women and $9 \mathrm{mg}$ in men $^{13}$. Furthermore, the results for calcium were similar when the analysis was restricted to women who did not report using any dietary supplements.

The results of previous observational studies of the association between dietary calcium and fracture risk in women have been inconsistent. In a meta-analysis of observational studies of dietary calcium published between 1966 and 1997, Cumming and Nevitt estimated that a $300 \mathrm{mg} \mathrm{day}^{-1}$ increase in calcium intake was associated with an odds ratio for hip fracture in post menopausal women of 0.96 (95\% CI $0.93-0.99)^{14}$. However, a later meta-analysis of observational studies estimated that a $300 \mathrm{mg} \mathrm{day}^{-1}$ increase in dietary calcium did not alter the risk of hip fracture in women (risk ratio 1.01 (95\% CI 0.96-1.07) $)^{15}$. Two publications from more recent large prospective studies have shown no association of calcium intake with hip fracture risk among 72000 postmenopausal women in the US Nurses' Health Study ${ }^{16}$ or with the risk for any osteoporotic fracture among 61000 women in the Swedish Mammography Screening Cohort $^{17}$, whereas a recent large case-control study in California $^{18}$ found a $50 \%$ higher risk for fracture of the proximal humerus among women with a calcium intake $<496 \mathrm{mg} \mathrm{day}^{-1}$ than among women with a calcium intake $>969 \mathrm{mg} \mathrm{day}^{-1}$.

The results from trials of the effect of supplemental calcium on fracture risk in women are also unclear. In a Cochrane review, the estimated fracture risks after treatment with calcium were 0.79 (95\% CI 0.54-1.09) for vertebral fracture and 0.86 (95\% CI $0.43-1.72)$ for nonvertebral fracture ${ }^{19}$. In two subsequent randomised controlled trials, women allocated to calcium supplementation did not have a reduced fracture rate ${ }^{20,21}$, but in one of these trials there was some evidence that the fracture rate was reduced among women who were compliant with the treatment ${ }^{21}$.

There are few previous data on calcium intake and fracture rates in men $^{22}$. We observed no significant association between calcium intake and fracture risk in men, but the number of fractures among men and the proportion of men with a low calcium intake were low. 
Table 3 Numbers of incident fractures and incidence rate ratios ( $95 \%$ Cls) by daily nutrient intake in women and men*

\begin{tabular}{|c|c|c|c|c|}
\hline \multirow[b]{2}{*}{ Nutrient and category } & \multicolumn{2}{|c|}{ Women } & \multicolumn{2}{|c|}{ Men } \\
\hline & $n$ & $\begin{array}{c}\text { Incidence } \\
\text { rate ratio }(95 \% \mathrm{Cl})\end{array}$ & $n$ & $\begin{array}{c}\text { Incidence } \\
\text { rate ratio }(95 \% \mathrm{Cl})\end{array}$ \\
\hline $\begin{array}{c}\text { Calcium (mg) } \\
<525 \\
525-699 \\
700-899 \\
900-1199 \\
\geq 1200^{\circ}\end{array}$ & $\begin{array}{l}129 \\
193 \\
335 \\
517 \\
381\end{array}$ & $\begin{array}{l}P<0.001 \dagger \\
1.75(1.33-2.29) \\
1.34(1.07-1.66) \\
1.15(0.96-1.37) \\
1.05(0.91-1.22) \\
1.00\end{array}$ & $\begin{array}{r}25 \\
38 \\
59 \\
111 \\
101\end{array}$ & $\begin{array}{l}P=1.00 \\
1.15(0.63-2.09) \\
0.94(0.59-1.49) \\
0.91(0.62-1.32) \\
1.02(0.76-1.37) \\
1.00\end{array}$ \\
\hline $\begin{array}{c}\text { Protein }(\mathrm{g}) \\
<55 \ddagger \S \\
55-64 \S \\
65-74 \S \\
75-89 \S \\
\geq 90 \S\end{array}$ & $\begin{array}{l}321 \\
241 \\
264 \\
367 \\
362\end{array}$ & $\begin{array}{c}P=0.39 \\
1.00 \\
0.87(0.72-1.05) \\
0.86(0.70-1.05) \\
0.98(0.78-1.22) \\
0.97(0.74-1.27)\end{array}$ & $\begin{array}{l}77 \\
46 \\
67 \\
77 \\
76\end{array}$ & $\begin{array}{l}P=0.46 \\
1.00 \\
0.79(0.52-1.18) \\
1.25(0.82-1.90) \\
1.19(0.74-1.91) \\
1.29(0.72-2.31)\end{array}$ \\
\hline $\begin{array}{l}\text { Vitamin D }(\mu \mathrm{g}) \\
<1.2 \ddagger \\
1.2-1.9 \\
2.0-2.7 \\
2.8-3.9 \\
\geq 4.0\end{array}$ & $\begin{array}{l}297 \\
307 \\
335 \\
281 \\
335\end{array}$ & $\begin{array}{c}P=0.55 \\
1.00 \\
0.97(0.82-1.15) \\
1.05(0.88-1.27) \\
1.07(0.87-1.31) \\
1.01(0.82-1.24)\end{array}$ & $\begin{array}{l}84 \\
69 \\
64 \\
64 \\
62\end{array}$ & $\begin{array}{l}P=0.68 \\
1.00 \\
0.96(0.68-1.37) \\
0.96(0.65-1.42) \\
1.13(0.74-1.72) \\
0.91(0.59-1.41)\end{array}$ \\
\hline $\begin{array}{l}\text { Vitamin } C(\mathrm{mg}) \\
\quad<80 \ddagger \\
80-119 \\
120-159 \\
160-199 \\
\geq 200\end{array}$ & $\begin{array}{l}212 \\
354 \\
425 \\
243 \\
321\end{array}$ & $\begin{array}{c}P=0.37 \\
1.00 \\
0.79(0.66-0.94) \\
0.95(0.79-1.15) \\
0.87(0.70-1.09) \\
1.06(0.83-1.36)\end{array}$ & $\begin{array}{r}65 \\
103 \\
96 \\
41 \\
38\end{array}$ & $\begin{array}{l}P=0.17 \\
1.00 \\
1.05(0.75-1.46) \\
1.23(0.85-1.78) \\
1.03(0.64-1.63) \\
1.10(0.65-1.88)\end{array}$ \\
\hline $\begin{array}{c}\text { Retinol }(\mu \mathrm{g}) \\
<200 \ddagger \\
200-299 \\
300-449 \\
450-999 \\
\geq 1000\end{array}$ & $\begin{array}{l}289 \\
299 \\
398 \\
367 \\
202\end{array}$ & $\begin{array}{c}P=0.97 \\
1.00 \\
0.96(0.80-1.14) \\
0.99(0.82-1.19) \\
1.03(0.84-1.27) \\
0.93(0.73-1.18)\end{array}$ & $\begin{array}{l}75 \\
58 \\
81 \\
85 \\
44\end{array}$ & $\begin{array}{l}P=0.54 \\
1.00 \\
0.92(0.62-1.36) \\
0.97(0.65-1.45) \\
0.91(0.58-1.42) \\
0.80(0.47-1.34)\end{array}$ \\
\hline $\begin{array}{c}\text { Carotene }(\mu \mathrm{g}) \\
<2000 \ddagger \\
2000-2999 \\
3000-3999 \\
4000-4999 \\
\geq 5000\end{array}$ & $\begin{array}{l}329 \\
348 \\
374 \\
186 \\
318\end{array}$ & $\begin{array}{c}P=0.51 \\
1.00 \\
1.09(0.94-1.28) \\
1.06(0.90-1.24) \\
1.03(0.85-1.25) \\
1.14(0.95-1.37)\end{array}$ & $\begin{array}{r}102 \\
81 \\
72 \\
42 \\
46\end{array}$ & $\begin{array}{l}P=0.29 \\
1.00 \\
0.87(0.64-1.17) \\
0.85(0.61-1.19) \\
1.04(0.70-1.53) \\
0.89(0.59-1.35)\end{array}$ \\
\hline $\begin{array}{c}\text { Potassium (mg) } \\
<3000 \ddagger \\
3000-3499 \\
3500-3999 \\
4000-4499 \\
\geq 4500\end{array}$ & $\begin{array}{l}289 \\
275 \\
313 \\
278 \\
400\end{array}$ & $\begin{array}{c}P=0.09 \\
1.00 \\
0.94(0.78-1.14) \\
0.96(0.77-1.20) \\
1.05(0.81-1.36) \\
1.17(0.86-1.60)\end{array}$ & $\begin{array}{l}47 \\
59 \\
78 \\
66 \\
93\end{array}$ & $\begin{array}{l}P=0.57 \\
1.00 \\
0.85(0.56-1.31) \\
0.85(0.53-1.35) \\
0.68(0.39-1.18) \\
0.54(0.27-1.05)\end{array}$ \\
\hline $\begin{array}{l}\text { Magnesium (mg) } \\
<275 \ddagger \\
275-324 \\
325-374 \\
375-449 \\
\geq 450\end{array}$ & $\begin{array}{l}320 \\
307 \\
309 \\
356 \\
263\end{array}$ & $\begin{array}{c}P=0.48 \\
1.00 \\
0.90(0.75-1.08) \\
0.85(0.69-1.05) \\
0.92(0.72-1.17) \\
0.95(0.69-1.30)\end{array}$ & $\begin{array}{l}41 \\
44 \\
75 \\
92 \\
91\end{array}$ & $\begin{array}{l}P=0.61 \\
1.00 \\
0.77(0.48-1.22) \\
1.14(0.71-1.82) \\
0.94(0.56-1.60) \\
0.82(0.42-1.59)\end{array}$ \\
\hline
\end{tabular}

$\mathrm{Cl}$ - confidence interval.

* Incidence rate ratios are stratified by method of recruitment and adjusted for age, smoking, intakes of energy and each other nutrient, alcohol consumption, body mass index, walking, cycling, vigorous exercise, other exercise, physical activity at work, marital status and, for women, parity and use of hormone replacement therapy (see Methods for details).

†The $P$-values relate to tests of trend, with the logarithm of nutrient intake replacing the categorical nutrient intake variable in the model.

$\ddagger$ Reference group.

$\S$ Category limits are $5 \mathrm{~g}$ higher for men.

Compared with other prospective studies in Western countries, the current study has a similar quality of assessment of calcium intake, but the range of calcium intake may be wider due to the targeted recruitment of people with varied dietary patterns ${ }^{6}$. Our estimates of calcium intake can be directly compared with those from the EPIC-Norfolk cohort, which used the same dietary questionnaire as EPIC-Oxford but in a general population sample in the UK; the mean intakes of calcium are almost identical in the two cohorts, but the standard deviations 
Table 4 Numbers of incident fractures and incidence rate ratios $(95 \% \mathrm{Cls})$ in relation to daily calcium intake among women aged $<50$ years or $\geq 50$ years at recruitment ${ }^{\star}$

\begin{tabular}{lcccr}
\hline & \multicolumn{2}{c}{ Women aged $<50$ years } & \multicolumn{2}{c}{ Women aged $\geq 50$ years } \\
\cline { 2 - 4 } Calcium intake $(\mathrm{mg})$ & $n$ & Incidence rate ratio $(95 \% \mathrm{Cl})$ & $n$ & Incidence rate ratio $(95 \% \mathrm{Cl})$ \\
\hline$<525$ & 71 & $2.06(1.38-3.06)$ & 100 & $1.53(1.05-2.23)$ \\
$525-699$ & 93 & $1.38(1.00-1.91)$ & 186 & $1.31(0.98-1.77)$ \\
$700-899$ & 149 & $1.23(0.94-1.61)$ & 313 & $1.10(0.87-1.39)$ \\
$900-1199$ & 204 & $1.06(0.84-1.33)$ & 231 & $1.05(0.87-1.27)$ \\
$\geq 1200 \dagger$ & 150 & & & 1.00 \\
& & $P<0.001 \ddagger$ & & $P=0.20$ \\
\hline
\end{tabular}

$\mathrm{Cl}$ - confidence interval.

*Incidence rate ratios are stratified by method of recruitment and adjusted for age, smoking, intakes of energy, protein, vitamins $\mathrm{D}$ and $\mathrm{C}$, retinol, carotene, potassium and magnesium, alcohol consumption, body mass index, walking, cycling, vigorous exercise, other exercise, physical activity at work, marital status, parity and use of hormone replacement therapy (see Methods for details).

†Reference group.

$¥$ The $P$-values relate to tests of trend, with the logarithm of calcium intake replacing the categorical nutrient intake variable in the model.

are about $20 \%$ larger for both women and men in EPICOxford than in EPIC-Norfolk ${ }^{6,23}$. Other differences between this study and previous observational studies are that previous studies have concentrated on post menopausal women and particularly on hip fractures, whereas the current study included adult women and men of all ages and examined risk for all types of fractures (except for digits and ribs). In our study, the association of dietary calcium with fracture risk was stronger among women under 50 years old than among older women. A previous systematic review of dairy foods and bone health concluded that the strongest evidence for a benefit of dairy foods was among women under 30 years old, perhaps because a benefit is most likely during the period of maximum bone accretion ${ }^{24}$. These observations suggest that more data on calcium and fracture risk in young women would be valuable.

Our results reinforce the importance of ensuring that women consume enough calcium to reach the UK reference nutrient intake of $700 \mathrm{mg} \mathrm{day}^{-1}$. Mean total calcium intakes in the UK fell by $>200 \mathrm{mg} \mathrm{day}^{-1}$ between 1970 and 1996 due to declines in the consumption of both milk and fortified bread ${ }^{1}$. The recent UK National Diet and Nutrition Survey ${ }^{13}$ estimated mean intakes from food during 2000-2001 as 777 and 1007 mg day $^{-1}$ in women and men, respectively, with $14 \%$ of women and $4 \%$ of men consuming $<500 \mathrm{mg} \mathrm{day}^{-1}$. The food groups contributing most to calcium intake in this survey were milk and milk products (43\%), cereals and cereal products (30\%), and fruit and vegetables (7\%). The large contribution from cereals is mainly due to the mandatory fortification of most types of flour in the UK with calcium ${ }^{13}$.

We observed no evidence that the other nutrients examined were associated with fracture risk. For protein, it has been hypothesised both that high protein intakes might increase fracture risk by increasing calcium excretion, and that high protein intakes could help to reduce fracture risk, for example by increasing production of insulin-like growth factor- ${ }^{25}$. Vitamin D is important for bone health; we did not observe any association of estimated dietary vitamin $\mathrm{D}$ with fracture risk, but the majority of vitamin D is produced by the action of sunlight on the skin, and we plan to investigate the role of vitamin $\mathrm{D}$ status in a nested case-control study of plasma 25-hydroxyvitamin D. For vitamin C, carotene, potassium and magnesium, it has been suggested that high intakes of these nutrients may benefit bone health and reduce fracture risk $^{26}$, but these hypotheses were not supported by our data. For retinol, some recent studies have observed an increase in fracture risk among people with very high consumption ${ }^{27,28}$. We observed no association between dietary retinol consumption and risk, but average dietary retinol intakes were low.

In conclusion, this study suggests that calcium intakes below $525 \mathrm{mg} \mathrm{day}^{-1}$ substantially increase the risk for fractures among women, and data from the National Diet and Nutrition Survey suggest that a large number of women in the UK may have calcium intakes low enough to put them at increased risk for fractures ${ }^{13}$.

\section{Acknowledgements}

Sources of funding: The EPIC-Oxford study is supported by the Medical Research Council and Cancer Research UK. R.E.N. was supported by a National Health and Medical Research Council (Australia) Sidney Sax fellowship.

Conflict of interest declaration: None.

Authorship responsibilities: T.J.K. is the principal investigator of the EPIC-Oxford cohort study P.N.A. conducted the analysis. All co-authors contributed to writing the paper. T.J.K. is the guarantor.

Acknowledgements: We thank the participants in EPICOxford.

\section{References}

1 Department of Health. Nutrition and Bone Health: With Particular Reference to Calcium and Vitamin D. Report on Health and Social Subjects No. 49. London: The Stationery Office, 1998. 
2 Department of Health. Dietary Reference Values for Food Energy and Nutrients for the United Kingdom. Report on Health and Social Subjects No. 41. London: HMSO, 1991.

3 Institute of Medicine. Dietary Reference Intakes for Calcium, Phosphorus, Magnesium, Vitamin D, and Fluoride. Washington, DC: National Academy Press, 1997.

4 Heaney RP. Calcium needs of the elderly to reduce fracture risk. Journal of the American College of Nutrition 2001; 20(Suppl.): 192S-7S.

5 Prentice A. What are the dietary requirements for calcium and vitamin D? Calcified Tissue International 2002; 70: 83-8.

6 Davey GK, Spencer EA, Appleby PN, Allen NE, Knox KH, Key TJ. EPIC-Oxford: lifestyle characteristics and nutrient intakes in a cohort of 33883 meat-eaters and 31546 non meat-eaters in the UK. Public Health Nutrition 2003; 6: 259-69.

7 Bingham SA, Gill C, Welch A, Cassidy A, Runswicke SA, Oakes S, et al. Validation of dietary assessment methods in the UK arm of EPIC using weighed records, and 24-hour urinary nitrogen and potassium and serum vitamin $C$ and carotenoids as biomarkers. International Journal of Epidemiology 1997; 26(Suppl. 1): S137-51.

8 Holland B, Welch AA, Unwin ID, Buss DH, Paul AA, Southgate DAT. McCance \& Widdowson's The Composition of Foods. Cambridge: Royal Society of Chemistry, 1991.

9 Stata Corporation. Stata Statistical Software: Release 9.0. College Station, TX: Stata Corporation, 2005.

10 Nevitt MC, Cummings SR, Browner WS, Seeley DG, Cauley JA, Vogt TM, et al. The accuracy of self-report of fractures in elderly women: evidence from a prospective study. American Journal of Epidemiology 1992; 135: 490-9.

11 Chen Z, Kooperberg C, Pettinger MB, Bassford T, Cauley JA, LaCroix AZ, et al. Validity of self-report for fractures among a multiethnic cohort of postmenopausal women: results from the Women's Health Initiative observational study and clinical trials. Menopause 2004; 11: 264-74.

12 Bingham SA, Gill C, Welch A, Day K, Cassidy A, Khaw KT, et al. Comparison of dietary assessment methods in nutritional epidemiology: weighed records v. $24 \mathrm{~h}$ recalls, food-frequency questionnaires and estimated-diet records. British Journal of Nutrition 1994; 72: 619-43.

13 Henderson L, Irving K, Gregory J, Bates CJ, Prentice A, Perks J, et al. The National Diet \& Nutrition Survey: Adults aged 19 to 64 years, Vol.3. Norwich: The Stationery Office, 2003.

14 Cumming RG, Nevitt MC. Calcium for prevention of osteoporotic fractures in postmenopausal women. Journal of Bone and Mineral Research 1997; 12: 1321-9.

15 Xu L, McElduff P, D'Este C, Attia J. Does dietary calcium have a protective effect on bone fractures in women? A meta-analysis of observational studies. British Journal of Nutrition 2004; 91 : 625-34.

16 Feskanich D, Willett WC, Colditz GA. Calcium, vitamin D, milk consumption, and hip fractures: a prospective study among postmenopausal women. American Journal of Clinical Nutrition 2003; 77: 504-11.

17 Michaelsson K, Melhus H, Bellocco R, Wolk A. Dietary calcium and vitamin D intake in relation to osteoporotic fracture risk. Bone 2003; 32: 694-703.

18 Chu SP, Kelsey JL, Keegan TH, Sternfeld B, Prill M, Quesenberry CP, et al. Risk factors for proximal humerus fracture. American Journal of Epidemiology 2004; 160: $360-7$.

19 Shea B, Wells G, Cranney A, Moher D, Adachi R, Treleaven D, et al. Calcium supplementation on bone loss in postmenopausal women. Cochrane Database Systematic Review 2004; 1: CD004526.

20 Grant AM, Avenell A, Campbell MK, McDonald AM, MacLennan GS, McPherson GC, et al. Oral vitamin D3 and calcium for secondary prevention of low-trauma fractures in elderly people (Randomised Evaluation of Calcium Or vitamin D, RECORD): a randomised placebo-controlled trial. Lancet 2005; 365: 1621-8.

21 Prince RL, Devine A, Dhaliwal SS, Dick IM. Effects of calcium supplementation on clinical fracture and bone structure: results of a 5-year, double-blind, placebo-controlled trial in elderly women. Archives of Internal Medicine 2006; 166: 869-75.

22 Owusu W, Willett WC, Feskanich D, Ascherio A, Spiegelman D, Colditz GA. Calcium intake and the incidence of forearm and hip fractures among men. Journal of Nutrition 1997; 127: 1782-7.

23 Bingham SA, Welch AA, McTaggart A, Mulligan AA, Runswick SA, Luben $\mathrm{R}$, et al. Nutritional methods in the European Prospective Investigation of Cancer in Norfolk. Public Health Nutrition 2001; 4: 847-58.

24 Weinsier RL, Krumdieck CL. Dairy foods and bone health: examination of the evidence. American Journal of Clinical Nutrition 2000; 72: 681-9.

25 Ginty F. Dietary protein and bone health. Proceedings of the Nutrition Society 2003; 62: 867-76.

26 Nieves JW. Osteoporosis: the role of micronutrients. American Journal of Clinical Nutrition 2005; 81: 1232S-9S.

27 Melhus H, Michaelsson K, Kindmark A, Bergstrom R, Holmberg L, Mallmin H, et al. Excessive dietary intake of vitamin A is associated with reduced bone mineral density and increased risk for hip fracture. Annals of Internal Medicine 1998; 129: 770-8.

28 Feskanich D, Singh V, Willett WC, Colditz GA. Vitamin A intake and hip fractures among postmenopausal women. Journal of the American Medical Association 2002; 287: $47-54$. 